\title{
OD WCZUCIA W CZLOWIEKA DO UNII MISTYCZNEJ Z BOGIEM
}

\section{Wprowadzenie}

Twórczość filozoficzna Edyty Stein, św. Teresy Benedykty od Krzyża, dzieli się - niejako w sposób naturalny - na trzy okresy: fenomenologiczny, metafizyczny i teologiczny, znaczone takimi pracami, jak: O zagadnieniu wczucia ${ }^{1}$ (Zum Problem der Einfühlung ${ }^{2}$ ) z roku 1917; Byt skonczony a byt wieczny. Próba wzniesienia się do sensu bytü (Endliches und ewiges Sein. Versuch eines Aufstiegs zum Sinn des Seins ${ }^{4}$ ) z roku 1937, będącą darem pożegnalnym Stein dla Niemiec, oraz Wiedza Krzyża. Studium o św. Janie od Krzyża (Kreuzeswissenschaft. Studie über Johannes vom Kreuz ${ }^{6}$ ) z roku 1942, stanowiącą jej filozoficzno-teologiczny testament. Twórczość filozoficzna Stein we wszystkich okresach jest - w szerokim rozumieniu tego słowa - monotematyczna, poświęcona człowiekowi; jest to antropologia fenomenologiczna, metafizyczna oraz teologiczno-mistyczna. W kontekście tych stwierdzeń należy powiedzieć, że wczucie jest pojęciem kluczowym dla zrozumienia rozwoju

${ }^{1}$ E. Stein, O zagadnieniu wczucia, tłum. D. Gierulanka i J.F. Gierula, Kraków 1988.

2 Taż, Zum Problem der Einfühlung, eingeführt und bearbeitet von M.A. Sondermann, Edith Stein Gesamtausgabe, Bd. 5, Freiburg im Breisgau 2008.

${ }_{3}^{3}$ Taż, Byt skończony a byt wieczny. Próba wzniesienia się do sensu bytu, tłum. J.I. Adamska OCD, Kraków 1995.

4 Taż, Endliches und ewiges Sein. Versuch eines Aufstiegs zum Sinn des Seins, eingeführt und bearbeitet von A.U. Müller, Edith Stein Gesamtausgabe, Bd.11/12, Freiburg im Breisgau 2006.

${ }^{5}$ Taż, Wiedza Krzyża. Studium o św. Janie od Krzyża, tłum. J.I. Adamska OCD, Kraków 2005.

6 Taż, Kreuzeswissenschaft. Studie über Johannes vom Kreuz, neu bearbeitet und eingeleitet von U. Dobhan OCD, Edith Stein Gesamtausgabe, Bd. 18, Freiburg im Breisgau 2008. 
filozoficznego i duchowego Stein i że doświadczenie istnienia drugiego człowieka wiedzie ją do doświadczenia istnienia osobowego Boga.

\section{Wczucie}

Problematyka wczucia jest naczelną problematyką Husserla i Stein ${ }^{7}$. W jakim sensie? Otóż Husserl w swoim rozwoju filozoficznym stanął przed problematyką solipsyzmu: istnienia jedynie podmiotu myślącego, „monady bez okien”. Myślący podmiot nie jest w stanie wyjść poza świadomość samego siebie, wszystko jest jego myśleniem i myślami. Ten solipsyzm trzeba było przezwyciężyć. Aby doświadczyć istnienia drugiej osoby ludzkiej, trzeba coś wiedzieć o istnieniu samego siebie. Stein jest zainteresowana byciem własnego bytu.

W analizach wczucia, Stein podąża drogą wyznaczoną przez Husserla8 i pokazuje na swój sposób, że byt człowieka nie przynależy tylko do sfery przyrodniczej, lecz przez świadomość uczestniczy w sferze ducha. Tak jak światem przyrodniczym rządzi prawo przyczynowości, tak światem ducha prawo motywacji. Zachowanie osoby jest zawsze, mniej lub bardziej, sensowne, dlatego należy szukać w nim związków motywacyjnych: "podmiot duchowy zgodnie ze swą istotą podlega prawom rozumu [...], jego przeżycia pozostają w zrozumiałych związkach" ${ }^{9}$. W świecie przyrody mamy prawa natury, w świecie ducha - prawa rozumu. Interpretacja czynu ludzkiego, jako świadomego czynu człowieka, może odbywać się tylko w sferze motywacji, nigdy w sferze przyczynowości. Działania drugiego człowieka, czyli jego osobowe akty, mają swe źródło w nim samym, jego wola te działania motywuje, dlatego człowiek jest odpowiedzialny za swoje czyny.

Praca doktorska Stein, przedłożona Wysokiej Radzie Wydziału Filozoficznego Uniwersytetu Wielkiego Księcia Badeńskiego Alberta Ludwika we Fryburgu Bryzgowijskim, nie zachowała się ani w manuskrypcie, ani w maszynopisie. Ze względów na powszechnie trudną sytuację finansową Edyta Stein otrzymała pozwolenie Wysokiej Rady na wydrukowanie tych części,

7 „Nawiązując do prac Theodora Lippsa, Husserl nazwał to doświadczenie «wczuciem» [die Einfühlung], ale nie określił, na czym ono polega. Była to luka, którą należało wypełnić: chciałam więc zbadać problem "wczucia»". E. Stein, Dzieje pewnej rodziny żydowskiej, tłum. J.I. Adamska OCD, Kraków 2005, s. 345.

${ }^{8}$ E. Husserl, Idee czystej fenomenologii i fenomenologicznej filozofii. Księga druga, tłum. D. Gierulanka, Warszawa 1974, s. 240 (rozdział: „Wczucie i konstytucja przyrody”).

${ }^{9}$ E. Stein, $O$ zagadnieniu ... , dz. cyt., s. 128. 
która uważała za najbardziej istotne ${ }^{10}$. Do pewnego stopnia można zrekonstruować układ pracy. W orzeczeniu promotora, Edmund Husserla, czytamy na temat dysertacji Stein:

W swojej dysertacji na temat Das Problem der Einfühlung in seiner geschichtlichen Entwicklung und in phänomenologischer Betrachtung panna E. Stein bada najpierw (cz[ęść] I) w niezależny sposób historię problemu wczucia, od przełomowych wywodów Herdera poczynając, a na współczesności kończąc. Szczególne znaczenie tej pracy polega na systematycznych badaniach części II-V dla fenomenologii wczucia z zastosowaniem ich w celu wyjaśnienia fenomenologicznych źródeł idei ciała, duszy, indywiduum, duchowej osobowości, wspólnoty społecznej i jej struktury. W obu ostatnich częściach badane jest znaczenie wczucia w sferze etycznej i estetycznej, a ostatecznie poddane jest fenomenologicznej analizie wczucia estetycznego.

Abstrahując od wywodów historycznych i krytycznych, aut[orka] kieruje się - w zasadniczych myślach swej teorii - moimi getyńskimi wykładami i osobistymi impulsami. Jednak wielki styl, z którym opracowuje owe impulsy, a także naukowa dokładność, jak i przenikliwość, którą wykazała, zasługują na najwyższe uznanie. Wznoszę stąd o dopuszczenie autorki do egzaminu ustnego.

Fryburg, 29 lipca 1916

E. Husserl ${ }^{11}$

Części I oraz V-VII nie zostały wydrukowane i uchodzą za zaginione. Do naszej dyspozycji pozostają: część II - Istota aktów wczucia, część III - Konstytucja indywiduum psychofizycznego i część IV - Wczucie jako rozumienie osób duchowych.

Stein twierdzi, że wczucie jest głównym źródłem wiedzy o życiu psychicznym drugiego człowieka. Ponieważ jest to poznanie "przedmiotu” będącego podmiotem, dlatego ma ono szczególny charakter, jest doświadczeniem: (1) bezpośrednim i naocznym, (2) czegoś zlokalizowanego w drugim podmiocie, (3) dlatego pozbawionym tak zwanej źródłowej naoczności, (4) w którym strona intelektualna zostaje uwzględniona razem ze stroną uczuciową ${ }^{12}$.

Od wczucia, w jego pełnym filozoficznym znaczeniu, należy odróżnić: "odczucie”, „wyczucie”, "przeczucie” czy „współczucie”, mające znaczenie psychologiczne. Wczucie nie jest "tylko moją sprawą" w tym sensie, że to ja sam, w taki czy inny sposób, potrafię dojść do psychiki drugiego człowieka i ją uchwycić. We wczuciu nie chodzi o to, aby podmiot wczuwający "coś"

10 E. Stein, Autoportret z listów, cz. 1: 1916-1933, tłum. J.I. Adamska OCD, A. Talarek, Kraków 2003, s. 25.

11 Tamże, s. 17. Oryginał znajduje się w aktach promocyjnych Edyty Stein z aktualną sygnaturą archiwum uniwersytetu we Fryburgu: B 42/1832.

${ }^{12}$ D. Gierulanka, Od ttumaczy, w: E. Stein, O zagadnieniu..., dz. cyt., s. 10. 
wczuwał, "wkładał" do podmiotu wczuwanego, i nie o to, aby podmiot wczuwający coś "wyciągał”, "wyrywał” z podmiotu wczuwanego, jak i również nie oto, aby oba podmioty „zatrzymały” się na przeżywaniu samego siebie ${ }^{13}$.

Wczucie jest „spotkaniem” podmiotu z podmiotem. Wczucie, o które chodzi w fenomenologii, nie jest również „zbiorowym przeżyciem” mniejszej lub większej grupy ludzi, wyrażającym się we wspólnym nastroju prowadzącym do jedności, identyfikacji członków z grupą. Wczucie nie jest "czuciem-się-jednym", "zlaniem się" podmiotu poznającego z podmiotem poznawanym, w którym „nie ma różnicy między własnym a cudzym Ja, lecz obydwa są jednym" 14 .

Doświadczenie istnienia drugiego podmiotu, jego życia wewnętrznego, nie „rodzi się" w spostrzeżeniu zewnętrznym czy spostrzeżeniu wewnętrznym, opisywanym w teorii naśladowania, teorii kojarzenia czy teorii wnioskowania analogicznego. Jedynie przez wczucie mamy dostęp do życia psychicznego drugiego podmiotu. Jest to akt swoistego rodzaju. Stein opisuje ową swoistość na przykładzie radości:

Żyjąc w owej radości kogoś drugiego, nie odczuwam źródłowej radości, nie wytryska ona żywo z mojego Ja, nie nosi też charakteru będącej - niegdyś - żywą, tak jak przypominana radość, lecz o wiele mniej jeszcze jest wyobrażoną tylko [radością przyp. J.M.], pozbawioną rzeczywistego życia; natomiast ów inny podmiot obdarzony jest źródłowością, choć ja tej źródłowości nie przeżywam, jego płynąca z niego [samego - przyp. J.M.] radość jest radością źródłową, choć ja jej jako źródłowej nie przeżywam. W moim nie źródłowym przeżywaniu czuję się niejako wiedziona przez przeżywanie źródłowe, nie doświadczane przez mnie, a jednak obecne, dające znać o sobie w moim nie źródłowym przeżywaniu. Tak więc w dokonywaniu wczucia mamy pewien rodzaj aktów doświadczenia sui Genesis ${ }^{15}$.

Aby „otworzyć się" na rzeczywistość drugiej osoby, aby wczuć w cudze Ja, muszę wznieść się na poziom istnienia duchowego. Czy to już wystarczy? Czy moje „otwarcie” równa się „przyjęciu” drugiego? „Ten, kto nigdy nie napotkał osoby godnej miłości lub nienawiści, nie potrafi nigdy przeżyć tych głębi, w jakich zakorzeniona jest miłość i nienawiść"16. Mogę się zatem „otworzyć" i mimo to nie przyjąć pełnej rzeczywistości drugiej osoby, gdyż

13 Por. R. Körner OCD, Einfühlung - ein Grundakt der (christlichen) Spiritualität, w: U. Dobhan, R. Körner, Lebenzweisheit für unsere Zeit. Edith Stein als Lehrerin der Spiritualität, Leipzig 2001, s. 57.

14 Tamże, s. 58-59.

${ }^{15}$ E. Stein, O zagadnieniu ..., dz. cyt. s. 25.

16 Tamże, s. 145. 
moja własna osoba nie jest $\mathrm{w}$ pełni rozwinięta. $\mathrm{W}$ takim przypadku można mówić o „niedoskonałej osobie”. Między poznaniem drugiego i poznaniem siebie samego zachodzi taki związek, że im bardziej rozumiem samego siebie, tym bardziej jestem $w$ stanie zrozumieć drugiego, i odwrotnie. Stein pisze, że „rozumienie cudzej indywidualności jest związane z własną, [...] nasza struktura przeżyciowa wyznacza zakres tego, co dla nas zrozumia$\mathrm{le}^{\prime \prime} 17$.

Pojęcie wczucia u Stein analizuje Klaus Hedwig w pracy: Über den Begriff der Einfühlung in der Dissertationsschrift Edith Steins ${ }^{18}$; jego znaczenie dla Europy XXI wieku przybliżam z kolei w artykule: Zum Europa der Werte - auf dem Wege mit Edith Stein ${ }^{19}$.

Wczucie stanowi istotny element przeżywanej duchowości na drodze ludzkości w trzecie tysiąclecie. Globalizacja sprawia, że nie żyjemy „wśród nas". Społeczeństwo, a nawet rodzina, stają się między-religijne, między-kulturowe, przeniknięte wpływami obcymi dla własnej kultury. We wczuciu chodzi - jeśli tak można powiedzieć - o zachowanie własnej tożsamości i tożsamości drugiego. Należy podjąć wysiłek prawdziwego życia z drugim, a nie obok drugiego. Trzeba się coraz głębiej poznawać, lepiej rozumieć, wzajemnie cenić, co do pewnego stopnia zapewnia wgląd (Ein-sicht) w sposób myślenia i życia drugiego, którego ukoronowaniem jest wczucie: akt całego człowieka, jego rozumu i jego serca. „Bez świadomie przeżywanej duchowości wczucia stworzymy piekło na ziemi - i zniszczymy tę ziemię, temu możemy zapobiec tylko wspólnym wysiłkiem." 20

Jeśli rozumiem sam siebie, wtedy również mogę zrozumieć drugiego. Moja struktura przeżyciowa wyznacza zakres tego, co dla mnie jest zrozumiałe: co odpowiada mojej strukturze psychicznej, to też zostaje w przeżyciu doprowadzone do wypełnienia. Na co jestem zamknięty, duchowo ślepy, to mogę mieć jedynie w postaci prostego przedstawienia. Stein konkretyzuje tę prawdę życia duchowego na przykładzie spotkania ateisty z osobą głęboko wierzącą:

Mogę sama być niewierząca, a przecież rozumieć, że ktoś inny za swoją wiarę składa w ofierze wszystkie ziemskie dobra, jakie posiada. Widzę, że tak działa i we wczuciu [przypisuję - przyp. J.M.] mu, jako motyw tego działania, doświadczenie wartości,

17 Tamże, s. 148.

${ }_{18}$ Zamieszczony w: Edith Stein. Leben - Philosophie - Vollendung, hrsg. Von L. Elders, Rolduc 1990.

${ }_{19}$ Zamieszczony w: Lex divina er civitatis. Festschrift für Prof. H. Schambeck zum 75. Geburtstag, red. B. Banaszak, J. Machnacz, Wrocław 2009.

${ }^{20}$ R. Körner, dz. cyt., s. 74. 
której odpowiednik nie jest mi dostępny, i przypisuję mu warstwę osobową, jakiej sama nie posiadam. W ten sposób we wczuciu uzyskuję typ "hominis religiosi”, który ze swej istoty jest mi obcy, i rozumiem go, chociaż to, co występuje tam jako nowe dla mnie, stale będzie pozostawać niewypełnione ${ }^{21}$.

\section{Unia mistyczna}

Zwróćmy uwagę na problematykę mistycznego zjednoczenia człowieka z Bogiem:

Kto kieruje się ślepą wiarą, [kto] nie chce rzeczywiście niczego innego aniżeli Bóg, ten osiągnął najwyższy stopień, do jego może dojść człowiek z pomocą płaski Bożej. Jego wola jest zupełnie oczyszczona i wolna od wszelkich powiązań spowodowanych ziemskimi skłonnościami, a przez dobrowolne oddanie zjednoczona z wolą Bożą. Mimo to brak tu czegoś decydującego, by dojść do najwyższego zjednoczenia miłości, do zaślubin mistycznych 22 .

Stein wprowadza nas $\mathrm{w}$ niezmiernie złożoną i delikatną problematykę bezpośredniego doświadczenia Boga w przeżyciu mistycznym. Kto czegoś takiego nie przeżył, a tym samym „kto nie ma w tych sprawach doświadczenia, uzna to za przesadę" 23 .

Według św. Jana od Krzyża, za którym podąża Stein, zamieszkiwanie Boga w duszy może mieć charakter zamieszkiwania: (1) istotowego, (2) pełnego łaski, bądź (3) przekształcającego i przebóstwiającego w doskonałej miłości24. Bóg utrzymuje stworzenie $\mathrm{w}$ istnieniu, tym samym "mieszka" w nim, w sposób istotny jest w nim obecny. Bóg zamieszkuje w stworzeniu przez łaskę wtedy, jeśli ono potrafi Go świadomie przyjąć do siebie. Ponieważ osoba ludzka ma udział w bycie duchowym, dlatego też może przyjąć do siebie inny byt duchowy. Ale Bóg jest na tyle i tak obecny w duszy, na ile pozwala na to "zdolność przyjmowania przyjmującego". Zamieszkiwanie pełne łaski ma charakter osobowy.

Między zamieszkiwaniem istotowymi a pełnym łaski jest różnica stopnia. Natomiast różnice $\mathrm{w}$ obszarze zjednoczenia pełnego łaski mają charakter jakościowej intensywności. Obecność Boga w duszy przez łaskę zostaje zapoczątkowana $\mathrm{w}$ akcie wiary. Wiara jest przyjęciem za prawdziwe tego, co Bóg objawił człowiekowi, ze względu na prawdomówność samego Boga.

\footnotetext{
${ }^{21}$ E. Stein, O zagadnieniu ..., dz. cyt., s. 150

${ }^{22}$ Taż, Wiedza Krzyża..., dz. cyt., s. 234.

23 Tamże, s. 263.

24 Tamże, s. 235.
} 
Rozum naturalny nie jest $\mathrm{w}$ stanie objąć tajemnic Boga, dlatego poznanie przez wiarę jest "poznaniem ciemnym”. Wiara jest w pierwszym rzędzie sprawą rozumu. Rozum pobudza serce do miłości. $Z$ "nocy wiary” przechodzi dusza do uszczęśliwiającego oglądu i zjednoczenia z Bogiem. Ogląd jest sprawą serca, wnętrza duszy, wszystkich jej sił. Zamieszkiwanie Boga $\mathrm{w}$ duszy przez łaskę osiąga pełnię w mistycznym zjednoczeniu ${ }^{25}$.

Mistyczne zjednoczenie przekształca duszę, „zmienia” sposób jej istnienia: zostaje ona „ubóstwiona”. Ponieważ dusza całkowicie powierza się Bogu, Bóg odsłania przed nią i włącza ją w tajemnice Swojego życia. Aby dusza mogła całkowicie, absolutnie oddać się Bogu, musi zupełnie wyzbyć się stworzenia i samej siebie. Musi stać się absolutnie pusta, aby przyjać absolutną Pełnię. W mistycznym zjednoczeniu dusza „Wznosi” się ku Stwórcy, który jest powołaniem wszelkiego stworzenia.

Obecność Boga w duszy na poziomie wiary może być przez duszę niezauważona, gdyż „tylko mała liczba wybranych dochodzi do spostrzeżeniowego ujęcia trójjedynego Boga w swoim wnętrzu"26. Większość wierzących nie dąży do pełni zjednoczenia, do przejścia z poziomu wiary do poziomu mistycznego zjednoczenia.

Aby się stać całkowicie przenikniętą Bytem Bożym - a na tym opiera się doskonałe zjednoczenie w miłości - dusza musi być wolna od jakiegokolwiek innego bytu, wolna od wszystkich innych stworzeń i od samej siebie, jak to dobitnie przedstawił św. Jan. Miłość w swym najdoskonalszym wypełnieniu chce być jednym w wolnym, wzajemnym oddaniu ${ }^{27}$.

Dusza musi zwrócić się całym swoim istnieniem i całym swoim bytem do źródła istnienia i bytu. Ten zwrot jest jakby wbrew jej naturze. Potężna rzeczywistość przyrodniczego świata musi zostać przezwyciężona przez jeszcze potężniejszą rzeczywistość Boga.

W mistycznym zjednoczeniu Bóg "dotyka" swoją istotą wnętrza duszy, jej istoty. „Istotą zaś Boga jest Jego Byt i On sam. On sam jest Osobą, Jego Byt - bytem osobowym. Wnętrze duszy to jakby serce i ośrodek jej życia osobowego, a jednocześnie właściwe miejsce spotkania z innym życiem osobowym. Spotkanie się osoby z osobą możliwe jest tylko we wnętrzu, gdzie jedna osoba daje drugiej znać o swojej obecności"28. W stanie mistycznego zjednoczenia dusza ma żywe czucie (lebendige Fühlung) osobowego Boga.

\footnotetext{
${ }^{25}$ Por. tamże, s. 255.

26 Tamże, s. 237.

27 Tamże, s. 247.

28 Tamże, s. 249.
} 
Pozbawiwszy się wszystkiego, może dać Bogu tylko samą siebie. Dając zaś Bogu samą siebie, staje się z Nim jednym. Na tym też polega jej ubóstwienie. Mistyczne zaręczyny są zjednoczeniem z trójjedynym Bogiem.

Spotkanie duszy z Bogiem w wierze jest spotkaniem z Bogiem „skrytym w ciemnościach nocy wiary", dlatego też nie ma ono pełni charakteru spotkania osoby z osobą. Jeśli dusza jest w „żywym kontakcie” z Bogiem, doskonale zjednoczona z Nim w miłości, wtedy nie może być przed nią skryte, że uczestniczy w życiu trójjedynego Boga: ona musi osiągnąć czucie wszystkich trzech Osób. Mistyczne zjednoczenie duszy jest jej śmiercią dla świata i zmartwychwstaniem dla Boga ${ }^{29}$.

\section{Zakończenie}

Edyta Stein - święta współpatronka Europy, siostra Teresa Benedykta od Krzyża ${ }^{30}$ - rozpoczyna zamyślenie nad swoim istnieniem i tożsamością od czystego Ja, swoistego rodzaju konstruktu fenomenologicznego, od którego przechodzi do Ja osoby ludzkiej, Ja mającego swoją stronę cielesną, duszną i duchową, i dochodzi do JA Boga, które „jawi się" na granicy nieskończonej skończoności bytu przygodnego. Można powiedzieć, że w badaniach filozoficznych Stein „idzie”, „zmierza” ku samej sobie, próbuje zbliżyć się do źródła istnienia.

Wczucie w drugiego człowieka "prowadzi” Stein do przeżycia unii mistycznej z Bogiem. Jej życie i praca filozoficzna są świadectwem tego, że człowiek staje się przed obliczem drugiego, to znaczy przed obliczem drugiego człowieka i wobec Boga. Bycie człowieka jest współ-byciem. Droga człowieka do samego siebie we wczuciu w drugiego człowieka i w unii mistycznej z Bogiem jest fundamentalnym wydarzeniem $\mathrm{w}$ bycie człowieka, dlatego nabiera też fundamentalnego znaczenia dla przyszłości Europejek i Europejczyków ${ }^{31}$.

Teorii nie można oddzielać od praktyki, nawet tak zwane dysputy akademickie mają, wcześniej czy później, odniesienie do życia. Edyta Stein, jak nieliczni myśliciele, uprawiała filozofię na sposób Sokratesa. Jej zdaniem

29 Por. H.-B. Gerl, Unerbittliches Licht. Edith Stein: Philosophie - Mystik - Leben, Mainz 1991; A.U. Müller, Grundzüge der Religionsphilosophie Edith Steins, Freiburg 1992 (zwłaszcza rozdział: „Die Vollendung der Selbsthingabe im Gebet der Ruhe - Der Aufstieg als Aufstieg zur Wahrheit in der Zuwendung und Fülle des Schweigens").

${ }^{30}$ Por. F.J.S. Fermin, Losslassen - Edith Steins Weg von der Philosophie zur karmelitischen Mystik. Eine historische Untersuchung, Stuttgart 2007.

${ }^{31}$ Por. Mistyka nadzieja Europy, red. A. Baran OFM, Warszawa 2006. 
odkryta prawda ma charakter zobowiązujący, musi urzeczywistnić się w życiu. Jak Sokrates Daimonionowi, tak ona w swoim myśleniu dała się prowadzić "samym rzeczom". Jej sposób filozofowania był fenomenologicznym, istotowym czytaniem rzeczywistości, ten sposób filozofowania ze swej istoty, czyli z tego, czym "są same rzeczy”, prowadzi do Absolutu i to zupełnie innego rodzaju Absolutu niż absolut czystej świadomości.

Życie i twórczość Edyty Stein, jak rzadko w dziejach filozofii, zwłaszcza filozofii nowożytnej, stały się świadectwem ukochania Prawdy i bycia w Prawdzie. Tak w jej życiu, jak i w jej twórczości mamy do czynienia ze świadectwem ${ }^{32}$.

Niektórzy uważają powstanie filozofii dialogu za jedno z „największych duchowo-intelektualnych wydarzeń minionego wieku"33. Interpretują filozofię dialogu jako krzyk protestu wobec totalitaryzmów dwudziestego wieku. Filozofia dialogu ma swoje źródła w Biblii, to Bóg przemówił do człowieka, to w twarzy drugiego człowiek odkrywa oblicze Boga. Wczucie i mistyka są "krzykiem” protestu przeciw przedmiotowemu traktowaniu podmiotu, przeciw uprzedmiotowianiu osoby ludzkiej34. We wczuciu doświadczam „Innego", który staje się dla mnie „drugim” Ja, do którego zwracam się: Ty. Ja i Ty stanowią MY, tworzą wspólnotę osób.

\section{From Empathy to a Man into a Mystical Union with God}

\section{Summary}

The philosophical thought of Edith Stein is connected with her life: life (praxis) asks the question to which she responds (theoria). Her philosophical work shows her personality (it is focused on searching for the sense of her own existence), being at the same time personal (interested in a human being, at in discovering sense of our existence). Such à la Socrates philosophyseeksto comprehend life more thoroughly and thereby to change it. Stein's way to herself starts with phenomenological empathy for (feeling-into) another man, with the intuition of another human being's existence and with one's own casual existence, and ends in a mystical unification with God, in the experience of the fulfilment of one's existence in the existence of God. The life and thought of Edith Stein - Saint Teresa Benedicta of the Cross are the testimony of searching for the Truth (theoria) and of being in the Truth (praxis).

32 Por. A. Grzegorczyk, Filozofia światła Edyty Stein, Poznań 2004 s. 84 (zwłaszcza rozdział "Filozofia i świadectwo").

33 J. Galarowicz, E. Lévinasa inspiracje i konfrontacje, „Kwartalnik Filozoficzny” 2006, nr 3, s. 185.

34 Por. P. Biela, Einfühlung jako dialogiczność personalizmu fenomenologicznego Edith Stein, "Czasopismo Filozoficzne" 2009, nr 4/5, s. 115. 